\title{
Reputational Signals and Capital Acquisition When Insurance Companies Go Public
}

\author{
Richard B. Carter and Mark L. Power \\ College of Business at Iowa State University, 2333 Gerdin Business Building, Ames, IA 50011, U.S.A. \\ E-mails: rbcarter@iastate.edu; mpower@iastate.edu
}

We analyse reputational signals and decisions surrounding capital acquisition by examining 76 insurance firms going public from 1996 to 2006. We first explore the relationship between proxies for insurance firm reputation and initial public offering (IPO) underwriter reputation. In general, we find that more reputable underwriters market IPOs of more reputable insurers - insurers that are less risky, more likely to be life insurers and that have higher franchise value. These results suggest that underwriter and insurer reputations are aligned and send consistent signals. Second, we show that the market requires a higher return from riskier/less reputable insurers when they go public. When we compare the performance of our insurance company sample to a matched sample of non-insurance firms, we find that the greater reputational transparency of insurers allows the market to do a better job of determining future performance. Last, we conclude by showing empirically that franchise value and the reputational posture of the insurance firms are positively related. These results contribute to the growing body of knowledge on reputational risk management and should enhance capital acquisition strategies of insurance company managers.

The Geneva Papers (2012) 37, 485-508. doi:10.1057/gpp.2012.26

Keywords: insurance; reputation; capital; IPOs; investment banking

\section{Introduction}

The purpose of this paper is to contribute to the nascent body of knowledge on reputational risk management by analysing insurer efforts to mitigate reputational risk and the costs that are associated with reputational uncertainty when managers raise capital through an initial public offering (IPO) of common stock. This objective is accomplished by first empirically determining if IPO underwriter reputation and proxies for insurer reputation send consistent signals or if an information asymmetry exists. Second, we determine if the performance of insurers that acquire capital by going public aligns with a set of performance/reputation expectations. Last, we test the relation between franchise value and the reputational posture of the insurer.

We focus on insurance company reputational risk management efforts at the time of their IPO for a number of reasons: this approach allows us to test for the effectiveness of reputation management from a stakeholder perspective, determine if reputation management enhances insurer (corporate) strengths and enables us to link reputational and operational risk, which are all underdeveloped research areas as identified 
by Schanz. ${ }^{1}$ This focus allows us to explore the problem of information asymmetry between underwriters, managers and insurance company stakeholders by analysing insurance company performance at the IPO and beyond. It also provides a unique venue to examine complex-regulated firms and then differences between those that are not.

Further developing an understanding of reputational risk management is of critical importance to insurance managers and the industry due to the intangible nature and complexity of insurance products, their purpose (promise to pay), and vested public interest. ${ }^{2}$ Stewart ${ }^{3}$ points out that reputation is more important for insurers and the insurance industry than most other business, even when the purchase of insurance is for all practical purposes mandatory. He also suggests that the future of the life and annuity industry may depend upon the quality of its reputation.

This paper makes several contributions to the literature on IPOs and reputational risk management. While there has been a wealth of evidence concerning underwriter reputation and IPOs of non-financial firms, ${ }^{4}$ there has been very little related research for insurance firms. ${ }^{5}$ We extend the limited literature in this area by determining if underwriter reputation and proxies for insurer reputation are aligned. New to the literature is our analysis of relationships between insurance firm reputation variables, the ability to raise capital and insurance firm performance. Last, we also derive a metric to determine the relationship between franchise value and the reputational posture of the insurer.

Our results allow us to draw a number of conclusions. First, we find that at the time of the IPO, underwriters and insurance companies align based on reputation. Specifically, more reputable underwriters align with lower risk and more valuable insurers, that are larger, more likely to be a life insurer, have more insider shares in the offering, and the shares have relatively larger offer prices than those insurers that use a less reputable underwriter. Second, we show that the market requires a higher return from riskier/less reputable insurers when they go public. Third, when we compare the three-year match-adjusted buy-and-hold returns of our insurer and non-insurer sample, we find that the market in general views insurers as more reputable at the time of their IPO. Insurance firms are rewarded with higher three-year returns than our non-insurance firms for being less risky and using a more reputable underwriter. Last, we conclude by empirically showing that franchise value and the reputational posture of the insurance firms are positively related.

The remainder of this paper is organised in the following manner. In the next section, we provide background on reputation and reputational risk management. That section is followed by the development of the research question and supporting literature. Data and methodology are then discussed and empirical results are presented. A summary of findings and conclusions are drawn in the final section.

\footnotetext{
${ }^{1}$ Schanz (2006).

${ }^{2}$ Csiszar and Heidrich (2006).

${ }^{3}$ Stewart (2006).

${ }^{4}$ Beatty and Ritter (1986); Carter and Manaster (1990); Hughes (1986); Titman and Trueman (1986).

${ }^{5}$ An exception is Viswanathan (2006) who argues that more prestigious underwriters prefer to bring lower risk issues to market.
} 


\section{Insurer reputation and reputational risk management}

There are many discipline-specific definitions of reputation, most of which focus on communication, public information, trust and opinion. ${ }^{6}$ A general definition of corporate reputation is "A perceptual representation of a company's past actions and future prospects that describes the firm's overall appeal to all of its key constituents when compared with other leading rivals". A working definition of reputational risk for the insurance industry can be found in Schurmann ${ }^{8}$ where he presents the U.K.'s FSA definition of reputational risk as "the risk that the firm may be exposed to negative publicity about its business practices or internal controls, which could have an impact on the liquidity or capital of the firm, or cause a change in its credit rating". While a good reputation is earned, a reputation can be damaged very quickly and the repair process is usually long and expensive as public trust is difficult to regain.

Several articles discuss the relationship between reputation and firm value. Forstmoser and Herger ${ }^{9}$ state that enterprises with a good reputation accrue direct and indirect economic benefits, such as access to capital markets at lower rates, deeper customer loyalty, less volatile share price and others, that ultimately make the firm more competitive. They believe that insurance companies have a duty to manage their reputation at every opportunity although Stewart ${ }^{3}$ argues that attempts by insurance managers to manipulate their reputations will likely do more harm than good.

Stansfield ${ }^{10}$ suggests that reputation is an "intangible", but that a damaged reputation has tangible consequences like stock price declines, bank runs, sales declines, rating downgrades, regulatory interventions and increased litigation among others. He also identifies sources of reputational risks such as unethical or illegal management behaviour, accounting fraud, poor corporate governance and disclosure practices, high profile regulatory investigations or litigation, etc. In some cases, negative information cascade and managerial ineptitude damages a firm's reputation to a tipping point where erosion of the public's trust becomes so great that bankruptcy occurs. ${ }^{11}$

Gaultier-Gaillard and Louisot ${ }^{6}$ point out that reputation is an important factor in the determination of the intrinsic value of insurance firms. They suggest that reputation is a composite asset whose value is a function of several factors, such as governance, social responsibility, workplace talent, meeting expectations, regulatory compliance, communication and long-term financial performance. ${ }^{12}$ If these factors satisfy stakeholders' (investors, legal firms, regulators, employees, policyholders and the distribution salesforce expectations), firm value will be enhanced. ${ }^{8}$

\footnotetext{
${ }^{6}$ Gaultier-Gaillard and Louisot (2006).

${ }^{7}$ Fombrun (1996, p. 72).

${ }^{8}$ Schurmann (2006).

${ }^{9}$ Forstmoser and Herger (2006).

10 Stansfield (2006).

11 Power (1983) and DeAngelo et al. (1994).

${ }^{12}$ For more detailed discussion of these factors, see Rayner (2003).
} 
Because capital is allocated to business functions according to risk-based models, it makes reputational risk management extremely important at the industry, company and lines of business levels. ${ }^{5} \mathrm{~A}$ best practices approach to reputational risk management is an ongoing process of identifying and evaluating reputational risk, selecting and implementing risk treatments, and monitoring to ensure that the cost of reputational risk is minimised and firm value meets stakeholder expectations. Management must constantly search for ways to credibly convey insurers' value, risk and efforts to control it. Using reputation to signal value, reduce costs and increase transparency may be especially important when changing an insurance company's organisational form to acquire capital by taking it public.

\section{Research questions and relevant literature}

We attempt to empirically answer three research questions:

- Do IPO underwriter reputation and proxies for insurer reputation send consistent signals or does an information asymmetry exist?

- Does the performance of insurers that acquire capital by going public align with a set of performance/reputation expectations?

- Is the relation between franchise value and the reputational posture of the insurer aligned?

The examination of the hypotheses that are developed and discussed in the remainder of this section, is intended to answer the above-mentioned research questions and determine if a connection exists between reputation and decisions involving capital acquisition when insurance firms go public.

In order to answer our first research question, "Do IPO underwriter reputation and proxies for insurer reputation send consistent signals or does an information asymmetry exist?" we test the following hypothesis:

H1: The reputational characteristics of insurance firms are positively related to the reputation of their marketing underwriter.

The research linking underwriter reputation to the pricing and performance of firms going public is extensive ${ }^{4}$ and suggests that, for the average firm going public, a reliable signalling opportunity involves the choice of IPO underwriter. However, while exploration of this link for non-insurance firms is extensive, for insurance firms it is limited.

We argue that because the direct cost to the insurer of raising capital through an IPO is significant and there is potential for reputational damage to both the insurer and underwriter if the IPO is not fully subscribed, insurers and underwriters should align based on reputation. If the reputations of insurers and underwriters are not aligned, an information asymmetry would exist and adverse selection costs would be incurred. Empirically validating this behaviour would provide evidence of insurance managers' attempt to manage reputational risk and protect current and prospective stakeholder capital interests. 
Theoretical models developed by Beatty and Ritter, ${ }^{13}$ Carter and Manaster, ${ }^{14}$ Hughes, ${ }^{15}$ and Titman and Trueman ${ }^{16}$ explain the relationship between underwriter risk and value signal when firms go public. In general these models argue that the reputation of the underwriter is positively related to the quality of the firm and should translate into higher relative prices at the initial offering and in better longterm performance. Moreover, Carter et al. ${ }^{17}$ show that the relationship between several issuing firm characteristics and their underwriter's reputation is consistent over time. The literature suggests that the cost of the signal devolves to the underwriter as their reputation suffers if they take a firm that is riskier than their reputation allows and that underwriters manage the risk of IPOs to maintain their reputation. As much as a high risk insurance firm may want to use a very reputable underwriter, it is to the underwriter's advantage to refuse them. ${ }^{14}$ However, it could be argued that if insurers are opaque, less reputable insurance firms may try to contract with more reputable underwriters to gain an economic advantage from the information asymmetry. ${ }^{18}$

We answer our second research question, "Does the performance of insurers that acquire capital by going public align with a set of performance/reputation expectations?" by empirically determining if:

H2: The relative run-up in insurer market price at the IPO and long-run performance are related to their reputational characteristics.

Changing the organisational form of an insurer is newsworthy, time-consuming and expensive. Csiszar and $\mathrm{Heidrich}^{2}$ suggest that a period of significant corporate change increases informational asymmetry and the value of reputation as a signalling device increases in importance. At the time a firm goes public, conveying its risk and its value (reputation) becomes particularly critical because of the lack of the stockmarket's price discovery mechanism and performance revelation. Assuming that management/owners want to receive as near the intrinsic value of their stock as possible, they need a way to credibly signal that value to the market. Carter and Manaster ${ }^{14}$ show that one way low risk firms reveal their low risk characteristics is by selecting underwriters with high reputation and as a consequence, leave less money on the table. As Rock, ${ }^{19}$ Beatty and Ritter ${ }^{13}$ and Carter and Manaster ${ }^{14}$ point out, more (less) risky firms gravitate to the less (more) reputable underwriters and discount their offer prices more (less) from their expected value to clear the market. This in turn results, on average, in better long-run returns for firms marketed by more reputable underwriters. $^{20}$

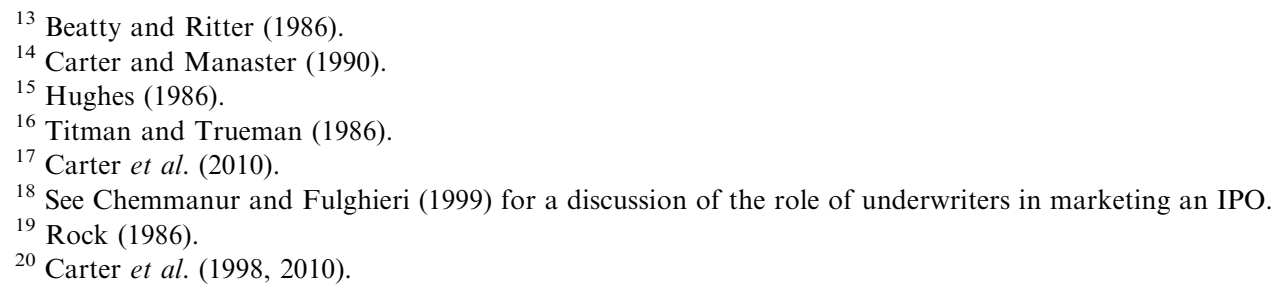


490

As we consider the effect of reputational signals on firm performance, the extent of information asymmetry for insurance firms compared to firms in general becomes an important topic. Information disclosure requirements at the federal and state levels for insurer public offerings create an especially unique laboratory to conduct research on insurer transparency and efforts to manage reputational risk. There is research that argues that regulated firms are subject to less asymmetry than non-regulated firms because of the scrutiny of the regulatory bodies. ${ }^{21}$ In a related work, Wang and Ligon $^{22}$ argue that lower information asymmetry for insurance firms affects their pricing. By comparing insurance firm IPOs to those of non-insurance firms they find that the adjustments to pre-offer pricing ranges are less for insurance firms than for non-insurance firms. Moreover, Lai et $a .^{23}$ find that these price-range adjustments explain the relative run-up in the initial offering price. Price-range adjustments are the result of the book-building process as underwriters gain information about the market value of IPOs. Both of these papers emphasise the importance of information asymmetry and how underwriter activities leading up to the offering reduce the asymmetry and are reflected in offering particulars.

Singh and Power ${ }^{24}$ point out that the conundrum for insurance company analysts is informational quality and relevance, not quantity. Zhang et al. ${ }^{25}$ discuss differences in sources of transparency for banks and insurers, identify relevant literature, and show that adverse selection costs increase as underwriting lines for property-casualty insurers become less transparent. Insurance companies' asset portfolios are generally considered harder to evaluate by outsiders than other financial institutions and industrials ${ }^{26}$ and Polonchek and Miller ${ }^{27}$ document greater information asymmetry for insurer assets and liabilities when compared to banks. Furthermore, it has been empirically shown that insurance company managers can create illusory values when insurance contracts are opaque and $\operatorname{complex}^{28}$ and that managerial discretion in setting property-liability loss reserves increases information asymmetry in investment markets. $^{29}$

Hence, if insurance firms are more (less) transparent, that should lead to less (more) of a need for a reputational signal than for non-insurance firms. However, that does not mean that more reputable insurance firms would not gravitate to more reputable underwriters to take advantage of their access to a broader range of buy-side clients, their superior skills in marketing and in designing offer particulars. ${ }^{30}$ It may also mean that the early after-market is a fairly good judge of the overall reputation (quality) of insurance firms.

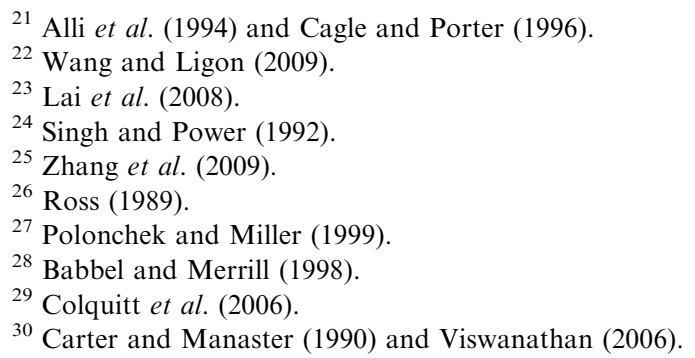


Our last research question allows us to empirically establish if "the relation between franchise value and the reputational posture of the insurer is aligned?" by testing the following hypothesis:

H3: The franchise value of insurance firms can be explained by their reputational posture and performance.

Babbel and Merrill ${ }^{31}$ argue that owners' equity, or stock value of an insurance company, has four major components: franchise value, put option value, market value of tangible assets and the present value of liabilities. They define franchise value as a function of the company's access to scarce resources-for example, reputation. Put option value arises whenever a stock firm issues debt, increasing as the firm takes on more risk. ${ }^{32}$ For insurance companies their policies are the major source of debt and valuing insurance firms is also complicated due to the complexity of their liabilities. ${ }^{33}$

Babbel and Merrill ${ }^{31}$ further explain that it is the quality of the insurance company's assets that primarily affect the put option value and franchise value. The problem with determining asset quality is that even with audited financial statements investors cannot be certain of accuracy. ${ }^{34}$ Colquitt and Hoyt ${ }^{35}$ argue that while market value and leverage are indicators that insurance firms are pre-disposed to controlling risk, reinsurance is a more reliable signal. Santomero and Babbel $^{36}$ outline the myriad risks insurance firms face, organising them into six categories: liquidity, actuarial, systematic, operational, credit and legal risks. In their explanation of the results of a survey they explain that insurance company management has worked to develop various ways to manage risk.

\section{Data}

Our sample includes all insurance firm IPOs issued from 1996 to 2006 that are included in the Thomson One SDC Platinum database. We limited our sample period for three reasons. First, as pointed out by Santomero and Babbel, ${ }^{36}$ there have been significant changes in the attention and management of risk by insurance firms beginning at some point in the early 1990s. Second, because our analysis requires unique and specific data collection concerning individual insurance companies we limited our analysis to those firms where we could obtain a complete, verifiable and final IPO prospectus and preliminary filings including all S1 filings. We used the SEC online database to collect these prospectuses and additional filings.

Information general to firms, for example, shares sold and retained by the firms' previous owners, the age of the firm at the IPO and the offering size, as well as specific company information are gleaned from this source. One of these unique data items is

\footnotetext{
${ }^{31}$ Babbel and Merrill (2005).

${ }^{32}$ Galai and Masulis (1976).

${ }^{33}$ Babbel et al. (2002) and Staking and Babbel (1995).

${ }^{34}$ See for example Beasley (1996) and Summers and Sweeney (1998).

${ }^{35}$ Colquitt and Hoyt (1997).

${ }^{36}$ Santomero and Babbel (1997).
} 
the average quality rating by Bests, Moodys, Standard and Poors and Duff and Phelps. We converted qualitative ratings to numeric values from zero (poor) to 15 (excellent) for each agency's rating. Finally, as one of our examinations requires the analysis of long-run returns we concluded our sample period in 2006 to allow for at least three years of returns to assess longer-term performance. The final sample includes 76 insurance company IPOs.

Because no commonly accepted and definitive insurance firm reputation measure exists we used variables extracted from the individual IPO prospectuses and preliminary filings as proxies. These include insurance company assets and liabilities, revenues, operating costs, net income, use of proceeds, outstanding litigation, risk factors, lines of business, distribution methods, domicile, use of reinsurance, the scope of the operation (i.e. regional, national or international) and pre-offering expected offer price ranges along with all changes.

Daily, monthly and buy-and-hold three-year returns as well as individual market prices for our sample and the market are from the Center for Research in Security Prices (CRSP). The standard deviation of daily returns and beta are calculated using CRSP daily returns from 50 market days post-IPO until 200 market days thereafter.

Underwriter reputation is estimated using the measure developed by Carter and Manaster $(\mathrm{CM})^{14}$ as a base. These rankings from zero to nine, where a zero represents the lowest reputation and nine the highest, are assigned according to placement in contemporaneous IPO tombstone advertisements. Loughran and Ritter $^{37}$ identify a possible flaw in CM where some investment banks that typically market lower-priced/ quality IPOs are listed with more prestigious underwriters and as a result are overranked by Carter and Manaster. ${ }^{14}$ As an objective response to this possible flaw, Carter et al. ${ }^{17}$ use the product of Carter and Manaster ${ }^{14}$ and the average offer price of IPOs marketed by the investment bank over a five-year period divided by 100 to estimate underwriter reputation (MODCM). ${ }^{38}$ While many of the firms had multiple underwriters, only the lead underwriter (book runner) was analysed-following Carter and Manaster ${ }^{14}$ among others. Summary statistics for the insurance sample are found in Table 1.

In many ways the firms in the sample appear to be of higher quality than the firms that have gone public over the last 25 years. Comparing Table 1 in this research to that of Carter et al., ${ }^{17}$ for example, underwriter reputation rank, net earnings, revenues, raw three-year return and the standard deviation of after-market return, often used as indicator of risk, are all better for the insurance company IPOs than the averages of their 6,686 firms. This may be an indication of the more stringent regulatory environment insurance companies experience before going public compared to the average firm as referred to above. In Table 2 Panel A, we have displayed the number of insurance IPOs issued in each year of the study along with the average gross

\footnotetext{
${ }^{37}$ Loughran and Ritter (2004).

${ }^{38}$ MODCM is similar to the measure developed by Ritter where the Carter and Manaster (1990) rank is adjusted downward for those investment banks that typically market IPOs with lower prices. The difference being that MODCM is the product of the underwriters' average IPO share price and the CM rank.
} 
Table 1 Summary statistics of 76 insurance firms

\begin{tabular}{|c|c|c|c|}
\hline Variable & Mean & Std dev & Median \\
\hline Offer price $(\$)$ & 16.30 & 5.96 & 16.00 \\
\hline Gross IPO proceeds (\$million) & 421.65 & 743.21 & 124.61 \\
\hline Market value (\$million) & 1,246 & 2,545 & 326.00 \\
\hline Age of firm at IPO (Years) & 24.22 & 39.70 & 6.00 \\
\hline Net income (\$million) & 111.34 & 229.96 & 22.45 \\
\hline Revenues (\$million) & 2,090 & 4,790 & 294.00 \\
\hline Total assets (\$million) & 16,472 & 50,718 & 732.00 \\
\hline Standard deviation of return $(\%)$ & 2.34 & 1.04 & 2.00 \\
\hline Debt to assets $(\%)$ & 62.81 & 81.63 & 84.44 \\
\hline Market beta & 0.67 & 0.57 & 0.54 \\
\hline Initial IPO return $(\%)$ & 10.49 & 14.58 & 7.08 \\
\hline Raw 3-year buy-\&-hold return (\%) & 54.72 & 111.34 & 34.90 \\
\hline Nasdaq-adjusted 3-year return (\%) & -22.31 & 107.41 & -36.00 \\
\hline Insiders selling shares with IPO (\%) & 14.83 & 29.24 & 0.00 \\
\hline Owners retention after IPO (\%) & 55.92 & 25.15 & 61.20 \\
\hline Carter/Manaster reputation rank & 8.23 & 1.15 & 8.92 \\
\hline Modified Carter/Manaster rank & 1.24 & 0.34 & 1.27 \\
\hline Tobin's $Q$ & 36.41 & 140.01 & 2.32 \\
\hline Market/book & 64.51 & 174.58 & 2.35 \\
\hline Variable & & & $\%$ \\
\hline Life insurers & & & 27.27 \\
\hline P\&C insurers & & & 45.46 \\
\hline Health insurers & & & 12.99 \\
\hline Agent marketing & & & 57.90 \\
\hline Use of re-insurance & & & 76.32 \\
\hline Demutualisation & & & 22.37 \\
\hline Insurance firms that delist for performance & & & 11.84 \\
\hline Treasury investments & & & 5.85 \\
\hline A or $>$ investments & & & 40.86 \\
\hline
\end{tabular}

proceeds of the offers and the average $\mathrm{CM}$ reputation rank of the lead underwriters for all offers in a given year. In Panel B we have listed all 76 firms with complete data.

Except for the year 2000, when only three went public, the numbers of insurance company IPOs have been quite consistent over the 11 years of our study. Moreover, the average reputation rank of underwriters also appears consistent.

In order to generalise our results, further analysis was undertaken using a timematched non-insurance sample. None of these firms were from financial or utility industries. Information for the non-insurance firms was obtained from the Thomson One database, the Compustat database and Moody's.

\section{Methods and results}

\section{Hypothesis $\mathrm{HI}$}

To test the first hypothesis, the relation between reputational characteristics of insurance firms, including their franchise value, and the reputation of their marketing 
Table 2 (a) Panel A: Insurance IPOs by year of issuance; (b) Panel B: 76 insurance firms

\begin{tabular}{lccc}
\hline Year & IPOs & Gross proceeds (\$million) & Carter/Manaster repu \\
\hline a) & & & \\
1996 & 5 & $\$ 82.20$ & 8.71 \\
1997 & 6 & $\$ 174.92$ & 8.78 \\
1998 & 6 & $\$ 141.15$ & 7.64 \\
1999 & 6 & $\$ 82.33$ & 8.00 \\
2000 & 3 & $\$ 1,581.02$ & 8.42 \\
2001 & 8 & $\$ 918.33$ & 8.37 \\
2002 & 7 & $\$ 764.71$ & 8.86 \\
2003 & 11 & $\$ 312.98$ & 8.01 \\
2004 & 9 & $\$ 711.35$ & 7.91 \\
2005 & 8 & $\$ 77.01$ & 7.86 \\
2006 & 7 & $\$ 246.78$ & 8.41 \\
Average & 6.91 & $\$ 421.65$ & 8.23 \\
Standard deviation & 2.12 & $\$ 480.08$ & 0.41
\end{tabular}

Firm name

IPO date

(b)

American States Financial

23 May 1996

Fbl Financial Group Inc

Farm Family Holdings Inc

19 July 1996

Fpic Insurance Group Inc

23 July 1996

Symons International Corp

1 August 1996

Amerus Life Holdings Inc

5 November 1996

Scpie Holdings Inc

29 January 1997

Trigon Healthcare Inc

30 January 1997

Old Guard Group Inc

31 January 1997

Hartford Life Inc

19 February 1997

Paula Financial

22 May 1997

American Safety Insurance

24 October 1997

Annuity \& Life Re Holdings

13 February 1998

Clark Bardes Holdings Inc

9 April 1998

$21^{\text {ST }}$ Century Holding Company

19 August 1998

Mony Group Inc

5 November 1998

Scottish Annuity Life Holdings

11 November 1998

Insurance Mgmt Solns Grp Inc

24 November 1998

American National Financial

11 February 1999

Stancorp Financial Group Inc

12 February 1999

National Med Health Card Svs

16 April 1999

Miix Group Inc

28 July 1999

Health Extras

30 July 1999

Hancock John Financial Svc

9 December 1999

Metlife Inc

27 January 2000

5 April 2000

American Physicians Capital

7 December 2000

Odyssey Re Holdings Corp

13 June 2001

Phoenix Cos Inc

20 June 2001

Max Re Capital

13 August 2001

Principal Financial Group Inc

23 October 2001

Anthem Inc

29 October 2001

Amerigroup Corp

5 November 2001 
Table 2 (continued)

\section{Firm name}

(b)

Centene Corp Del

Prudential Financial

Travelers Ppty Casualty Co

Hub Intl Ltd

Montpelier Holdings

U S I Holdings Corp

Platinum Underwriters Hldg

Safety Insurance Group Inc

Infinity Property \& Casualty

Endurance Specialty Holding

National Financial Partners

Axis Capital Holdings Ltd

Molina Healthcare Inc

Direct General Corp

American Equity Invt Life

Aspen Insurance Holdings Ltd

China Life Insurance Co Ltd

United National Group Ltd

Mercer Insurance Group Inc

Assurant Inc

Bristol West Holdings Inc

Procentury Corp

Assured Guaranty Ltd

Genworth Financial Inc

Wellcare Group Inc

Affirmative Insurance Hldg

Specialty Underwriters All

K M G America Corp

Seabright Insurance Holdings

National Interstate Corp

National Atlantic Holdings

Republic Companies Group Inc

James River Group Inc

North Pointe Holdings Corp

Amerisafe Inc

Crm Holdings Ltd

Amcomp

Ram Holdings Ltd

Allied World Assurance Co Holdings

Security Capital Assurance

Ehealth Inc

First Mercury Financial

Onebeacon Insurance Group
IPO date

12 December 2001

13 December 2001

21 March 2002

18 June 2002

9 October 2002

21 October 2002

28 October 2002

21 November 2002

11 February 2003

27 February 2003

9 May 2003

1 July 2003

1 July 2003

11 August 2003

3 December 2003

3 December 2003

11 December 2003

15 December 2003

16 December 2003

4 February 2004

11 February 2004

20 April 2004

22 April 2004

24 May 2004

30 June 2004

9 July 2004

17 November 2004

15 December 2004

21 January 2005

28 January 2005

21 April 2005

3 August 2005

9 August 2005

23 September 2005

18 November 2005

16 December 2005

2 February 2006

26 April 2006

7 July 2006

28 July 2006

6 October 2006

17 October 2006

3 November 2006

underwriter, we use ordinary least squares (OLS) regressions. The dependent variable is the modified Carter and Manaster $^{14}$ reputation rank (MODCM) regressed on reputational characteristics and control variables. Because an exact expression of franchise value (FVAL) is illusive, we define it operationally as Zhang et al. $^{25}$ and 
others do, with a selection of descriptive variables. ${ }^{39}$ Among these variables are market-to-book (MTB) and Tobin's $Q(Q)$. Both MTB and $\mathrm{Q}$ are argued to be related to franchise value. ${ }^{40}$ Tobin's $Q$ is commonly defined as: ${ }^{41}$

$$
Q=\frac{[\text { Market Value of Equity }+ \text { Book Value of Liabilities }]}{\text { Total Assets }} \text {. }
$$

FVAL of an insurer, in turn, is dependent on reputation (Staking and Babbel ${ }^{42}$ ). However, MTB has also been used as a risk measure - with a negative relation to potential long-run returns and value. ${ }^{43}$ The empirical model is found in Eq. (2).

$$
\mathrm{MODCM}=\alpha+B Q+B P+B C+\varepsilon,
$$

where $B Q$ is a vector of the product of the two FVAL variables outlined above and coefficients and $B P$ is a vector of the product of variables that have been used in IPO studies to indicate a firm's potential value. ${ }^{44} B C$ is a vector of two control variables and coefficients and $\varepsilon$ is the error term.

In the following we explain each variable, control variable and the expected relation to MODCM based on H1. We have included an example of empirical evidence supporting our predictions if one exists. The expected relations are predicated to some extent upon the assumption that more reputable underwriters tend to gravitate to insurance firms with greater franchise value (Table 3).

\begin{tabular}{|c|c|c|}
\hline Variable & Construction & Expected relation to $M O D C M$ \\
\hline \multicolumn{3}{|c|}{ FVAL variables } \\
\hline MTB & Market value/book value of equity & Negative: Higher MTB means riskier firms ${ }^{43}$ \\
\hline Q & Tobin's $Q$ & $\begin{array}{l}\text { Positive: Insurer value is dependent on } \\
\text { reputation }{ }^{2}\end{array}$ \\
\hline \multicolumn{3}{|l|}{ IPO variables } \\
\hline STD & $\begin{array}{l}\text { Standard deviation of after-market return } \\
\text { expressed as a decimal, where lower STD } \\
\text { means less risk }\end{array}$ & $\begin{array}{l}\text { Negative: Better underwriters market firms } \\
\text { with lower less risk }{ }^{45}\end{array}$ \\
\hline LNPROC & $\begin{array}{l}\text { Natural logarithm of the gross proceeds } \\
\text { from the IPO adjusted for inflation }\end{array}$ & $\begin{array}{l}\text { Positive: Larger offerings are generally } \\
\text { marketed by more reputable underwriters }{ }^{46}\end{array}$ \\
\hline \multicolumn{3}{|c|}{$\begin{array}{l}39 \text { These variables are commonly used in IPO studies to indicate intrinsic risk and future performance. See } \\
\text { for example, Hanley et al. (1993); Johnson and Miller (1989) and Carter et al. (1998). }\end{array}$} \\
\hline \multicolumn{3}{|c|}{${ }^{40}$ See Keeley (1990) and Harrington (2004) p. 164.} \\
\hline \multicolumn{3}{|c|}{${ }^{41}$ See Hoyt and Liebenberg (2011). } \\
\hline \multicolumn{3}{|c|}{42 Staking and Babbel (1995). } \\
\hline \multicolumn{3}{|c|}{${ }^{43}$ Fama and French (1995). } \\
\hline \multicolumn{3}{|c|}{$\begin{array}{l}{ }^{44} \text { See for example, Ritter (1984); Carter and Manaster (1990); Fernando et al. (2004); Hanley et al. (1993) } \\
\text { and Johnson and Miller (1989). }\end{array}$} \\
\hline \multicolumn{3}{|c|}{45 Johnson and Miller (1989). } \\
\hline 46 Ritter (19 & & \\
\hline
\end{tabular}

Table 3 Franchise value and IPO variables 
Table 3 (continued)

\begin{tabular}{|c|c|c|}
\hline Variable & Construction & Expected relation to $M O D C M$ \\
\hline INSIDE & $\begin{array}{l}\text { The fraction of the total IPO shares that } \\
\text { are from those of the pre-IPO owners }\end{array}$ & $\begin{array}{l}\text { Positive: Insiders are urged to sell shares for } \\
\text { better IPOs }{ }^{47}\end{array}$ \\
\hline OFFPR & The offer price of the IPO & $\begin{array}{l}\text { Positive: Higher prices for higher quality } \\
\text { IPOs }^{48}\end{array}$ \\
\hline LNAGE & $\begin{array}{l}\text { The natural logarithm of the } 1+\text { the age } \\
\text { in years of the firm at the IPO }\end{array}$ & Positive: Older firms tend to be better firms ${ }^{46}$ \\
\hline RETAIN & $\begin{array}{l}\text { The fraction of total outstanding shares } \\
\text { after the IPO retained by pre-IPO } \\
\text { owners } 49\end{array}$ & $\begin{array}{l}\text { Positive: Insiders retain more of a firm likely } \\
\text { to outperform } 50\end{array}$ \\
\hline \multicolumn{3}{|c|}{ Control variables } \\
\hline LIFE & $\begin{array}{l}\text { Indicator }(0,1) \text { where } 1 \text { indicates the firm } \\
\text { is primarily a life insurance company }\end{array}$ & $\begin{array}{l}\text { The variable is included to control for } \\
\text { variation due to product differences among } \\
\text { firms }\end{array}$ \\
\hline YEAR & $\begin{array}{l}\text { The four-digit YEAR in which the firm } \\
\text { went public }\end{array}$ & $\begin{array}{l}\text { The variable is included to control for } \\
\text { variation due to timing }\end{array}$ \\
\hline
\end{tabular}

The standard errors are consistent using White's ${ }^{51}$ correction and the results of the regression are found in Table 4 Model 1.

The model is significant at better than the 1 per cent level and the adjusted $R^{2}$ of 0.581 suggests a good fit of the data. In general the coefficients and significance levels of the independent variables are consistent with other research and with our predictions. ${ }^{52}$ The results indicate that more reputable underwriters market the IPOs of insurance firms that are founded earlier, are significantly larger, with a greater increase in the partial adjustment, and where the existing owners retain a larger portion of the insurance firm. The coefficients for both franchise value variables are significant and while the coefficient for $\mathrm{Q}$ is consistent with reputation and FVAL, the negative coefficient for MTB is more consistent as a risk measure. The positive and significant coefficient for LIFE is consistent with the results of Stewart, ${ }^{3}$ where life insurance companies are more likely to use more reputable underwriters. ${ }^{53}$

As a follow-up examination we include the effect of pre-offer insurance firm characteristics variables to Eq. (2). These characteristics - from the offering prospectusesdetail the companies from several perspectives but are endemic to insurance companies. In the following, the construction of each of these characteristic variables

\footnotetext{
${ }^{47}$ Hanley et al. (1993).

${ }^{48}$ Fernando et al. (2004).

${ }^{49}$ As might be expected the correlation between RETAIN and INSIDE is negative. However, it is not significant.

${ }^{50}$ Leland and Pyle (1977).

${ }^{51}$ White (1980).

${ }^{52}$ See, for example, Carter and Manaster (1990), Carter et al. (1998) and Hanley (1993).

${ }^{53} \mathrm{We}$ also included the natural log of the firm's value in place of LNPR with similar results.
} 
Table 4 Ordinary least-squares regression: Modified Carter/Manaster rank (MODCM) regressed on insurance firm descriptive variables

\begin{tabular}{|c|c|c|c|c|}
\hline \multirow[t]{2}{*}{ Variable } & \multicolumn{2}{|c|}{ Model 1} & \multicolumn{2}{|c|}{ Model 2} \\
\hline & Coefficient & Test statistic ${ }^{\mathrm{a}}$ & Coefficient & Test statistic \\
\hline Intercept & -4.613 & -0.24 & 9.031 & 0.36 \\
\hline Market/book (MTB) & -0.001 & $-4.39 * * *$ & -0.001 & $-3.26^{* * *}$ \\
\hline Tobin's $Q(Q)$ & 0.001 & $3.45^{* * *}$ & 0.001 & $2.42 * *$ \\
\hline Standard deviation of return (STD) & -0.030 & -0.94 & -0.056 & -1.63 \\
\hline Nat log of IPO gross proceeds (LNPROC) & 0.060 & $2.03 * *$ & 0.055 & 1.66 \\
\hline Insiders selling shares with IPO (INSIDE) & 0.054 & 0.69 & 0.046 & 0.42 \\
\hline IPO offer price (OFFPR) & 0.027 & $4.65 * * *$ & 0.026 & $4.82 * * *$ \\
\hline Natural log of $1+$ age of firm (LNAGE) & 0.018 & 0.98 & 0.019 & 1.10 \\
\hline Shares retained by owners (RETAIN) & 0.350 & $3.43 * * *$ & 0.356 & $2.93 * * *$ \\
\hline Agent distribution $(1,0)$ (AGENT) & & & -0.025 & -0.43 \\
\hline Re-insurance (CEDE) & & & -0.054 & -0.65 \\
\hline Commercial $(1,0)(\mathrm{COMM})$ & & & -0.026 & -0.37 \\
\hline Extenuating circumstances $(1,0)(\mathrm{EXT})$ & & & 0.133 & 1.50 \\
\hline Investments $\geqslant A$ (INVEST) & & & 0.001 & 0.34 \\
\hline Number of litigations (LITS) & & & -0.036 & -0.92 \\
\hline Recent rating revisions $(1,0)$ (POSREV) & & & 0.003 & 0.24 \\
\hline Ranking (average: agencies) (RATE) & & & -0.093 & -1.17 \\
\hline Number of risks listed (RISKS) & & & 0.004 & 0.81 \\
\hline National scope $(1,0)$ (SCOPE) & & & 0.082 & 1.43 \\
\hline Number of uses listed (USES) & & & -0.047 & -0.64 \\
\hline Demutualisation $(1,0)$ (DEMUT) & & & 0.062 & 0.66 \\
\hline Life ins variable $(1,0)(\mathrm{LIFE})$ & 0.221 & $4.56^{* * *}$ & 0.199 & $3.70 * * *$ \\
\hline The year of IPO (YEAR) & 0.002 & 0.25 & -0.004 & -0.34 \\
\hline Adjusted $R^{2}$ & 0.581 & & 0.549 & \\
\hline Model significance & & $11.39 * * *$ & & $5.15 * * *$ \\
\hline
\end{tabular}

${ }^{a}$ The test statistic for the individual coefficients and the model is a $t$ and $F$ statistic, respectively. Standard errors are adjusted using White's (1980) correction. Significance at the 10, 5 and 1 per cent levels is indicated by one, two and three asterisks, respectively.

is explained and an expected relation to MODCM is provided. We have included an example of empirical evidence supporting our predictions if one exists (Table 5).

Table 5 Insurance firm characteristic variables

\begin{tabular}{|c|c|c|}
\hline Variable & Construction & Expected relation to $M O D C M$ \\
\hline AGENT & $\begin{array}{l}\text { Indicator }(0,1) \text { where a } 1 \text { indicates that } \\
\text { products are distributed by agents }\end{array}$ & $\begin{array}{l}\text { Negative: Risk decreases with human } \\
\text { interaction }\end{array}$ \\
\hline CEDE & $\begin{array}{l}\text { Indicator }(0,1) \text { where a } 1 \text { indicates that the } \\
\text { firm employs reinsurance }\end{array}$ & $\begin{array}{l}\text { Negative: Sharing risk lowers firm-specific } \\
\text { risk }\end{array}$ \\
\hline COMM & $\begin{array}{l}\text { Indicator }(0,1) \text { where a } 1 \text { indicates that } \\
\text { commercial lines products are offered }\end{array}$ & $\begin{array}{l}\text { Positive: Commercial lines products } \\
\text { increase risk }\end{array}$ \\
\hline EXT & $\begin{array}{l}\text { Indicator }(0,1) \text { where a } 1 \text { indicates that } \\
\text { some extenuating circumstance is } \\
\text { mentioned }\end{array}$ & $\begin{array}{l}\text { Positive: Firms reveal risk-increasing } \\
\text { events to avoid litigation }{ }^{54}\end{array}$ \\
\hline
\end{tabular}

\footnotetext{
54 Tinic (1988).
} 
Table 5 (continued)

\begin{tabular}{|c|c|c|}
\hline Variable & Construction & Expected relation to $M O D C M$ \\
\hline INVEST & $\begin{array}{l}\text { Per cent of investments that are rated A or } \\
\text { better }\end{array}$ & $\begin{array}{l}\text { Positive: Better investment should mean } \\
\text { less risk }\end{array}$ \\
\hline LITS & Number of litigations pending & $\begin{array}{l}\text { Positive: Potential legal problems } \\
\text { increases risk }\end{array}$ \\
\hline POSREV & $\begin{array}{l}\text { Indicator }(0,1) \text { where a } 1 \text { indicates a } \\
\text { positive pre-offer rating revision }\end{array}$ & Negative: Positive news is risk decreasing \\
\hline RATE & $\begin{array}{l}\text { Average quality indicator by rating } \\
\text { agencies from zero (poor) to } 15 \text { (excellent) }\end{array}$ & Negative: Higher quality_less risk \\
\hline RISKS & Number of risks listed in the prospectus & Positive: Self explanatory \\
\hline SCOPE & $\begin{array}{l}\text { Indicator }(0-1) \text { where } 1 \text { indicates a } \\
\text { regional, } 2 \text { national and } 3 \text { global } \\
\text { operations }\end{array}$ & $\begin{array}{l}\text { Risk increases with scope or decreases due } \\
\text { to geographic diversification }\end{array}$ \\
\hline USES & Number of uses listed in the prospectus & $\begin{array}{l}\text { Positive: Beatty and Ritter }{ }^{13} \text { use the } \\
\text { number of uses listed as a proxy for } \\
\text { risk }\end{array}$ \\
\hline
\end{tabular}

We have included one additional control variable, DEMUT where a 1 indicates that the IPO is part of the demutualisation process and 0 otherwise. The results are found in Table 4, Model 2. The standard errors are consistent using White's ${ }^{51}$ correction.

The model is significant at better than the 1 per cent level and the adjusted $R^{2}$ of 0.549 suggests a good fit of the data. With the exception of the coefficient for LNPROC, which is not significant in Model 2, the signs of the significant coefficients are similar to Model 1. The most important finding, however, is that none of the insurance firm characteristic variables are significant. We interpret this to mean that underwriters and insurance firms do not match-up based on unique insurance-specific characteristic variables but rather on the broader aspects of the firm and the offer. ${ }^{55}$ In general, we believe the two models support Hypothesis $\mathrm{H} 1$ and allow us to conclude that at the time of their IPO, underwriter and insurer reputations are aligned and send consistent signals.

\section{Hypothesis $\mathrm{H} 2$}

To test hypothesis $\mathrm{H} 2$, the anticipated negative relationship between the relative first-day IPO returns (under-pricing) and reputational proxies, we duplicate similar research, again using an OLS regression. The dependent variable is the initial return (IPORET), the relative difference between the closing bid price on the first day of

\footnotetext{
55 There has been evidence to suggest the market may look at firms with more suspicion since the collapse of Enron (see, for example, Rahman et al., 2009). As a result we included a binary variable where a 1 indicates years 2001-2006 and zero otherwise in each of the preceding analyses. However, the coefficient was never significant nor did its inclusion qualitatively alter the stated results.
} 
Table 6 Ordinary least squares regression: Initial (First-Day) return (IPORET) regressed on underwriter reputation and explanatory variables

\begin{tabular}{lrr}
\hline Variable & & Model 1 \\
\cline { 2 - 3 } & Coefficient & Test statistic \\
\hline Intercept & 4.035 & 0.29 \\
Market/book (MTB) & 0.001 & $5.01^{* * *}$ \\
Tobin's $Q(Q)$ & -0.001 & -1.15 \\
Modified Carter/Manaster rank (MODCM) & 0.022 & 0.22 \\
Nat log of IPO gross proceeds (LNPROC) & -0.026 & $-1.79^{*}$ \\
Insiders selling shares with IPO (INSIDE) & -0.045 & -0.94 \\
IPO offer price (OFFPR) & -0.001 & -0.18 \\
Natural log of 1+age of firm (LNAGE) & 0.001 & 0.11 \\
Shares retained by owners (RETAIN) & -0.016 & -0.27 \\
Offer price/expected offer price (PART) & 0.400 & $2.72^{* * *}$ \\
Life insurance variable (1,0) (LIFE) & -0.023 & -0.52 \\
Year of the offering (YEAR) & -0.002 & -0.30 \\
Adjusted $R^{2}$ & 0.211 & $2.67^{* * *}$ \\
Model significance $(F$ statistic) & & \\
\hline
\end{tabular}

The $t$ test statistics for the individual coefficients is in italics. Standard errors are adjusted using White's (1980) correction. Significance at the 10, 5 and 1 per cent levels is indicated by one, two and three asterisks, respectively.

trading and the offer price. We regress IPORET on the IPO analysis variables described above, including MODCM. ${ }^{56}$ The model is displayed in Eq. (3).

$$
\text { IPORET }=\alpha+B Q+B P+B C+\varepsilon,
$$

where $B Q$ is a vector of the product of coefficients and the FVAL variables, $B P$ is a vector of the product of coefficients and the IPO variables including MODCM and a partial adjustment variable (PART). PART is the offer price divided by the expected offer price (E(OFFPR)). $\mathrm{E}(\mathrm{OFFPR})$ is measured as the average of the minimum and maximum pre-IPO price range displayed in the first filed S1. Generally, PART is positively related to IPORET as underwriters do not fully adjust the offer price to encourage investors to reveal their true reservation price for the IPO.$^{57} \mathrm{BC}$ is a vector of two control variables and coefficients and $\varepsilon$ is the error term. The results of the regression are found in Table 6 . The standard errors are consistent using White's ${ }^{51}$ adjustment.

The model is significant at better than the 1 per cent level and the adjusted $R^{2}$ of 0.211 suggests a fairly good fit and consistent with earlier, similar results (see for example Carter et al. ${ }^{58}$ ). Three of the independent variables are significant, MTB, LNPROC and PART. These findings are consistent with our predictions and support the notion that IPORET increases with the risk of the offering firm. ${ }^{19}$

\footnotetext{
${ }^{56}$ See for example, Beatty and Ritter (1986); Carter and Manaster (1990); Hanley (1993) and Johnson and Miller (1989).

${ }^{57}$ Hanley (1993).

${ }^{58}$ Carter et al. (1998).
} 
The signalling value of many of the standard IPO characteristics, including the reputation of the marketing underwriter, is mitigated in Model 4. This finding is consistent with Derrien ${ }^{59}$ where he suggests that the abnormally large first-day IPO return has more to do with the effect of noise or sentiment traders driving up prices in the after-market than an intentional offer price discount. In either of these cases, intentional under-pricing or overly optimistic sentiment trading, it may be the regulatory environment of the insurance industry that adds efficiency to the process.

To test the other implication of hypothesis $\mathrm{H} 2$, we examine the relationship between the long-run returns of the insurance firms using their three-year, buy-andhold return - the relative difference between the after-market price following the IPO to a price three years later. Because of the nature of the return and the horizon, we adjust the long-run IPO return with a contemporaneous buy-and-hold return from a sample of non-insurance firms matched to each insurance firm by date (MATR3). MATR3 is regressed on the FVAL variables and control variables. The model is expressed in Eq. (4).

$$
\text { MATR3 }=\alpha+B Q_{I}+B Q_{N I}+B L_{I}+B L_{N I}+B C+\varepsilon,
$$

where $B Q$ is the product of vectors of coefficients and the FVAL variables, MTB and Q. The subscript designators, $I$ and $N I$, identify the observations for the insurance and non-insurance firms, respectively. $B L$ is the product of vectors of coefficients and variables that have been used in long-term return models (see, for example, Carter et $a .^{58}$ ). These variables include IPORET; MODCM; LNVAL, the natural logarithm of the equity market value of the firm at the IPO; and BETA, the market model beta as estimated in the after-market. Finally, $B C$ is a vector of coefficients and the two control variables, LIFE and YEAR and $\varepsilon$ is the error term. Standard errors are consistent using White's ${ }^{51}$ adjustment. The results are found in Table 7.

The model is significant at better than the 1 per cent level and the adjusted $R^{2}$ of 0.337 suggests a very good fit, especially for a long-run return model. While the coefficients for both $\mathrm{MTB}_{I}$ and $\mathrm{MTB}_{N I}$ variables are not significant, the coefficient for $Q_{I}$ is significant and negative for the insurance firms and suggests that a higher Tobin's $Q$ means less risk ${ }^{60}$ and as such less long-run return.

The coefficients for IPORET $_{I}$ and for IPORET $_{\mathrm{NI}}$ are positive and negative, respectively. The result implies that the market does a better job of determining future performance for insurance companies than for non-insurance firms. The positive and significant coefficient for $\mathrm{MODCM}_{N I}$ for non insurance firms - is consistent with work by Carter et $a l^{20}{ }^{2}$-whereas the coefficient for the insurance sample is not significant. This result suggests that there is a reputational signal from underwriter prestige but only for the non-insurance firms. This finding suggests greater reputational transparency for the insurance sample at the time of the IPO when compared to the sample of non-insurance firms. ${ }^{61}$ The totality of the empirical

\footnotetext{
${ }^{59}$ Derrien (2005).

${ }^{60}$ Keeley (1990).

${ }^{61}$ In a subsequent regression we include industry designators for the non-insurance firms as developed by Fama and French (1992). The coefficient for the industry designator variable was not significant and did nothing to qualitatively change our results.
} 
Table 7 Ordinary least squares regression: three-year match-adjusted buy-and-hold return (MATR3) regressed on initial return and explanatory variables

\begin{tabular}{|c|c|c|}
\hline \multirow[t]{2}{*}{ Variable $^{\mathrm{a}}$} & \multicolumn{2}{|c|}{ Model 1} \\
\hline & Coefficient & Test statistic \\
\hline Intercept & -9.971 & -0.10 \\
\hline Market/book ratio $\left(\mathrm{MTB}_{\mathrm{I}}\right)$ & 0.024 & 0.35 \\
\hline Market/book ratio $\left(\mathrm{MTB}_{\mathrm{NI}}\right)$ & 0.006 & 0.44 \\
\hline Tobin's $Q\left(\mathrm{MTB}_{\mathrm{I}}\right)$ & -0.001 & $-2.01 * *$ \\
\hline Tobin's $Q\left(\mathrm{MTB}_{\mathrm{NI}}\right)$ & -0.155 & -1.41 \\
\hline Initial return $\left(\right.$ IPORET $\left._{I}\right)$ & 2.835 & $2.12 * *$ \\
\hline Initial return $\left(\text { IPORET }_{\mathrm{NI}}\right)^{\mathrm{b}}$ & -1.195 & $-3.58 * * *$ \\
\hline Underwriter rank $\left(\mathrm{MODCM}_{\mathrm{I}}\right)$ & -0.293 & -0.37 \\
\hline Underwriter rank $\left(\mathrm{MODCM}_{\mathrm{NI}}\right)$ & 1.083 & $2.85^{* * *}$ \\
\hline Log of value $\left(\mathrm{LNVAL}_{\mathrm{I}}\right)$ & 0.272 & $1.77 *$ \\
\hline Log of value $\left(\mathrm{LNVAL}_{\mathrm{NI}}\right)$ & -0.005 & -0.03 \\
\hline $\operatorname{Beta}\left(\mathrm{BETA}_{\mathrm{I}}\right)$ & -0.130 & -0.52 \\
\hline $\operatorname{Beta}\left(\mathrm{BETA}_{\mathrm{NI}}\right)$ & -0.116 & -1.04 \\
\hline Binary life variable $(1,0)$ (LIFE) & 0.392 & 1.15 \\
\hline Year of the offering (YEAR) & 0.004 & 0.08 \\
\hline Adjusted $R^{2}$ & 0.337 & \\
\hline Model significance ( $F$ statistic) & & $3.64 * * *$ \\
\hline
\end{tabular}

${ }^{a}$ Each insurance firm (I) is matched with a non-insurance firm (NI) going public at the same time.

${ }^{\mathrm{b}}$ The test statistic for the individual coefficients and the model is a $t$ and $F$ statistic, respectively. Standard errors are adjusted using White's (1980) correction. Significance at the 10, 5 and 1 per cent levels is indicated by one, two and three asterisks, respectively.

findings relating to $\mathrm{H} 2$ confirms that the reputation and performance of insurers that acquire capital by going public are aligned.

\section{Hypothesis $H 3$}

The last hypothesis predicts that franchise value can be explained by the reputational posture and performance potential of the insurance firms at the IPO. For the dependent variable, franchise value, we derive a metric using factor analysis to flesh-out appropriate variables. The first factor (Eigenvalue $=4.20$ ) identified five variables with sufficient loading: the average quality indicator by rating agencies (RATE), net income pre-IPO, the natural logarithm of total assets (LNTA), Tobin's $Q(Q)$ and Debt/Assets. Using the factor loadings and signs for each variable we summed the weighted observations to produce the measure (EFVAL). We would argue that EFVAL should be indicative of the franchise value as well as the potential of each insurance firm at the IPO.

To test the relation between EFVAL and reputational posture at the IPO, we regress EFVAL on variables intended to reflect reputation. Using factor analysis and the first factor (Eigenvalue=3.26) we isolated 11 variables which, given the nature of the factor loadings, appear to be appropriate: MTB, STD, LNPROC, INSIDE, OFFPR, LNAGE, RETAIN MODCM, PART, LITS, SCOPE and the natural logarithm of revenue in the year preceding the IPO (LNREV). We include three control variables: 
LIFE, YEAR and the number of firms that provide pre-IPO ratings for each insurance firm (RATENO). The latter variable is included to control for any implication that a non rating may convey. The model appears in Eq. (5):

$$
\text { EFVAL }=\alpha+B X+B C+\varepsilon,
$$

where $B X$ is the product of vectors of coefficients and the ten test variables identified with factor analysis and described above and $B C$ is the product of vectors of coefficients and the control variables and $\varepsilon$ is the error term. The results appear in Table 8 , Model 1 .

The adjusted $R^{2}$ of 0.580 and significance of the model at better than the 1 per cent level suggest a good fit for the data. The positive and significant signs of the coefficients for LNPROC and RETAIN and the negative and significant sign for MTB indicates that franchise value and the reputational posture of the insurance firms are positively related. The negative sign for the offer price is counter intuitive as usually higher priced IPOs are indicative of better offerings. ${ }^{48}$ It may well be that with the other variables the marginal effect of OFFPR measures some other aspect of the insurance firm's fundamental qualities.

As a further test of performance potential and franchise value we looked at the relation between EFVAL and longer-term performance. The two test variables are a binary variable, DELIST, where a 1 indicates that the firm delisted at some point over the three years following the IPO because of poor performance and zero otherwise and MAR3 the three-year buy-and-hold return of the firm less the contemporaneous Nasdaq return. DELIST was used in addition to an adjusted return variable because of questions of validity of a market adjustment, providing a simple measure of performance and avoiding the survival bias of long-run returns and without having to rely on financial statement accuracy. ${ }^{62}$ As control variables we included MTB, MODCM, LNVAL, INVEST, RATENO, LIFE and YEAR. The results are found in Table 8 , Model 2.

The adjusted $R^{2}(0.534)$ and significance of the model at better than the 1 per cent level suggest a good fit of the data. The negative and significant coefficient for DELIST implies that the insurance firms with the higher franchise value are less likely to delist. The negative sign for MTB and the positive sign for LNVAL suggest that larger and less risky insurers have higher franchise and greater performance potential. These findings provide further support for the conclusion that franchise value and the reputational posture of the insurance firms are positively related.

\section{Summary and conclusions}

We contribute to the literature on reputational risk management by analysing 76 insurers' efforts to mitigate reputational risk and the costs that are associated with reputational uncertainty when capital is raised through an IPO of common stock. We first attempt to empirically determine if IPO underwriter reputation and proxies for

\footnotetext{
${ }^{62}$ Fama and French (2004) note that using survival/failure rates to examine changes in performance avoids any problems associated with "accounting rules".
} 
Table 8 (a) Ordinary least squares regression: Standard deviation (as a per cent) (STD) of after-market return regressed on insurance firm characteristic variables; (b) Ordinary least-squares regression: franchise value factor (EFVAL) regressed on: insurance firm reputation variables, performance and control variables ${ }^{\mathrm{a}}$

\begin{tabular}{|c|c|c|c|c|}
\hline \multirow[t]{2}{*}{ Variable } & \multicolumn{2}{|c|}{ Model 1} & \multicolumn{2}{|c|}{ Model 2} \\
\hline & Coefficient & Test statistic ${ }^{\mathrm{b}}$ & Coefficient & Test statistic \\
\hline \multicolumn{5}{|l|}{ (a) } \\
\hline Intercept & 256.136 & $3.01 * * *$ & 291.178 & $3.12 * * *$ \\
\hline Market/book (MTB) & 0.001 & 1.25 & -0.001 & -0.16 \\
\hline Tobin's $Q(Q)$ & -0.001 & -1.43 & -0.001 & -0.21 \\
\hline Agent distribution $(1,0)$ (AGENT) & -0.462 & $-2.1 * *$ & -0.423 & $-2.10 * *$ \\
\hline Re-insurance (CEDE) & -0.613 & $-2.55^{* *}$ & -0.472 & $-1.86^{*}$ \\
\hline Commercial $(1,0)(\mathrm{COMM})$ & 0.056 & 0.29 & -0.023 & -0.13 \\
\hline Extenuating circumstances $(1,0)(\mathrm{EXT})$ & 0.859 & 1.46 & 0.696 & 1.24 \\
\hline Investments $\geqslant A$ (INVEST) & 0.005 & 1.14 & 0.005 & 1.10 \\
\hline Number of litigations (LITS) & -0.110 & -0.78 & -0.066 & -0.38 \\
\hline Recent rating revisions $(1,0)$ (POSREV) & -0.141 & $-2.59 * *$ & -0.107 & $-1.99 * *$ \\
\hline Ranking (average: agencies) (RATE) & 0.033 & 0.11 & -0.122 & -0.52 \\
\hline Number of risks listed (RISKS) & 0.027 & $2.33 * *$ & 0.031 & $2.74 * * *$ \\
\hline National scope $(1,0)$ (SCOPE) & 0.250 & 0.98 & 0.306 & 1.11 \\
\hline Number of uses listed (USES) & 0.311 & $1.79 *$ & 0.134 & 0.60 \\
\hline Nat log of IPO gross proceeds (LNPROC) & -0.203 & -0.87 & -0.327 & -1.17 \\
\hline Demutualisation $(1,0)$ (DEMUT) & -0.127 & $-2.98 * * *$ & 0.199 & $1.90 *$ \\
\hline Insiders selling shares with IPO (INSIDE) & & & -0.496 & -1.62 \\
\hline IPO offer price (OFFPR) & & & -0.042 & $-1.81 *$ \\
\hline Natural log of $1+$ age of firm (LNAGE) & & & 0.043 & 0.59 \\
\hline Shares retained by owners (RETAIN) & & & 0.768 & 1.51 \\
\hline Modified Carter/Manaster rank (MODCM) & -0.279 & -0.92 & -0.706 & $-2.08 * *$ \\
\hline Binary life variable $(1,0)$ (LIFE) & -0.279 & -0.92 & -0.200 & -0.63 \\
\hline Year of the offering (YEAR) & -0.127 & -2.98 & -0.144 & $-3.08 * * *$ \\
\hline Adjusted $R^{2}$ & 0.324 & & 0.389 & \\
\hline Model significance & & $3.24 * * *$ & & $3.17 * * *$ \\
\hline Variable & Coefficient & Test statistic ${ }^{\mathrm{c}}$ & Coefficient & Test statistic \\
\hline \multicolumn{5}{|l|}{ (b) } \\
\hline Intercept & 236.975 & 1.62 & 180.943 & 1.31 \\
\hline Market/book (MTB) & -0.005 & $-2.32 * *$ & -0.006 & $-2.27 * *$ \\
\hline Standard deviation of return (STD) & 0.100 & 0.47 & & \\
\hline Nat log of IPO gross proceeds (LNPROC) & 1.483 & $5.06^{* * *}$ & & \\
\hline Insiders selling shares with IPO $^{2}$ (INSIDE) & 0.348 & 0.5 & & \\
\hline IPO offer price (OFFPR) & -0.127 & $-2.47 * *$ & & \\
\hline Natural log of $1+$ age of firm (LNAGE) & 0.025 & 0.19 & & \\
\hline Shares retained by owners (RETAIN) & 1.948 & $2.2 * *$ & & \\
\hline Modified Carter/Manaster rank (MODCM) & 0.204 & 0.22 & -1.420 & -1.67 \\
\hline Offer price/expected offer price (PART) & -1.095 & -0.84 & & \\
\hline Number of litigations (LITS) & 0.538 & 1.59 & & \\
\hline National scope $(1,0)$ (SCOPE) & 0.111 & 0.26 & & \\
\hline Natural log of pre-IPO revenues (LNREV) & 0.458 & 1.19 & & \\
\hline Delisted performance reasons $(1,0)$ (DELIST) & & & -1.893 & $-2.67 * *$ \\
\hline Market adjusted 3-year return (MAR3) & & & -0.115 & -0.67 \\
\hline Log of market value (LNVAL) & & & 1.446 & $4.13 * * *$ \\
\hline Investments $\geq \mathrm{A}$ (INVEST) & & & 0.002 & 0.36 \\
\hline
\end{tabular}


Table 8 (continued)

\begin{tabular}{lccrc}
\hline Variable & Coefficient & Test statistic & Coefficient $^{\text {Test statistic }}$ \\
\hline Number of rating firms (RATENO) & 0.038 & 0.21 & 0.089 & 0.47 \\
Bin life ins variable $(1,0)$ (LIFE) & 0.040 & 0.07 & 0.805 & 1.35 \\
Year of IPO (YEAR) & -0.122 & $-1.68^{*}$ & -0.089 & -1.35 \\
Adjusted $R^{2}$ & 0.580 & & 0.534 & $10.43^{* * *}$ \\
Model significance $(F$ statistic) & & $7.81^{* * *}$ & & 10 \\
\hline
\end{tabular}

${ }^{a}$ Franchise Value Factor is a weighted linear combination of the following variables: the average quality indicator by rating agencies from zero (poor) to 15 (excellent), net income, the natural logarithm of total assets, Tobin's $Q$, Debt/Assets and the per cent of owners retaining shares in the company at the offering, weighted by the factor analysis signs and loadings.

${ }^{\mathrm{b}}$ The test statistic for the individual coefficients and the model is a $t$ and $F$ statistic, respectively. Standard errors are adjusted using White's (1980) correction. Significance at the 10, 5 and 1 per cent levels is indicated by one, two and three asterisks, respectively.

${ }^{\mathrm{c}}$ Significance at the 10,5 and 1 per cent levels is indicated by one, two and three asterisks, respectively.

insurer reputation send consistent signals or if an information asymmetry exists. Next, we explore the relationship between the initial and long-run performance of insurers that acquire capital by going public with a set of reputation proxies and a matched sample of non-insurance firms. Last, we develop a metric for franchise value and then test the relation between franchise value and the reputational posture of the insurer.

A number of conclusions can be drawn from the empirical analysis undertaken in this paper. First, we find that at the time of the IPO, underwriters and insurance companies align based on reputation. Specifically, more reputable underwriters align with lower risk and more valuable insurers, that are larger, more likely to be a life insurer, have more insider shares in the offering, and the shares have relatively larger offer prices than those insurers that use a less reputable underwriter. Second, we show that the market requires a higher return from riskier/less reputable insurers when they go public. Third, when we compare the three-year match-adjusted buy-and-hold returns of our insurer and non-insurer samples, we find that the market in general views insurers as more reputable at the time of their IPO. Insurance firms are rewarded with higher three-year returns than our non-insurance firms for being less risky and using a more reputable underwriter. Last, we empirically show that franchise value and the reputational posture of the insurance firms are positively related.

Our approach allowed us to test for the effectiveness of reputation management and explore the problem of reputational asymmetry between underwriters, managers and insurance company stakeholders. This approach also provided a unique venue to examine complex-regulated firms and then differences between those that are not. Our findings further the understanding of reputational risk mitigation and should be of interest to insurance managers and the industry due to the importance of reputation in the determination of the intrinsic value of insurance firms.

\section{References}

Alli, F., You, J. and Yung, K. (1994) 'The underpricing of IPOs of financial institutions', Journal of Business, Finance and Accounting 21(7): 1013-1030. 
Babbel, D., Gold, J. and Merrill, C. (2002) 'Fair value of liabilities: The financial economics perspective', North American Actuarial Journal 6(1): 12-27.

Babbel, D. and Merrill, C. (1998) 'Economic valuation models for insurers', North American Actuarial Journal 2(3): 97-144.

Babbel, D. and Merrill, C. (2005) 'Real and illusory value creation by insurance companies', Journal of Risk and Insurance 72(1): 1-21.

Beasley, M. (1996) 'An empirical analysis of the relation between the board of directors composition and financial statement fraud', The Accounting Review 71(4): 443-465.

Beatty, R. and Ritter, J. (1986) 'Investment banking, reputation and the under-pricing of initial public offerings', Journal of Financial Economics 15(1\&2): 213-232.

Cagle, J. and Porter, G. (1996) 'IPO underpricing in regulated industries', Journal of Economics and Finance 20(1): 27-37.

Carter, R., Dark, F. and Sapp, T. (2010) 'Underwriter reputation and IPO issuer alignment 1981-2005', Quarterly Review of Economics and Finance 50(4): 443-445.

Carter, R., Dark, F. and Singh, A. (1998) 'Underwriter reputation, initial returns, and the long-run performance of IPO stocks', Journal of Finance 53(1): 285-311.

Carter, R. and Manaster, S. (1990) 'Initial public offerings and underwriter reputation', Journal of Finance 45(4): 1045-1068.

Chemmanur, T. and Fulghieri, P. (1999) 'A theory of the going-public decision', The Review of Financial Studies 12(2): 249-279.

Csiszar, E. and Heidrich, G.W. (2006) 'The question of reputational risk: Perspectives from and industry', The Geneva Papers on Risk and Insurance - Issues and Practice 31(3): 382-394.

Colquitt, L. and Hoyt, R. (1997) 'Determinants of corporate hedging behavior: Evidence from the life insurance industry', Journal of Risk and Insurance 64(4): 649-671.

Colquitt, L., Hoyt, R. and McCullough, K. (2006) 'The impact of asbestos and environmental reserved increases on shareholder wealth', North American Actuarial Journal 10(3): 17-31.

DeAngelo, H., DeAngelo, L. and Gilson, S.C. (1994) 'The collapse of first executive corporation: Junk bonds, adverse publicity, and the "run on the bank" phenomenon', Journal of Financial Economics 36(3): 287-336.

Derrien, F. (2005) 'IPO pricing in "Hot" market conditions: Who leaves money on the table?' Journal of Finance 60(1): 487-521.

Fama, E. and French, K. (1992) 'The cross-section of expected stock returns', Journal of Finance 47(2): 427-465.

Fama, E. and French, K. (1995) 'Size and market to book measures in earnings and returns', Journal of Finance 50(1): 131-155.

Fama, E. and French, K. (2004) 'New lists: Fundamentals and survival rates', Journal of Financial Economics 73(2): 229-269.

Fernando, C., Krishnamurthy, S. and Spindt, P. (2004) 'Are share price levels informative? Evidence from the ownership, pricing, turnover and performance of IPO firms', Journal of Financial Markets 7(4): 377-403.

Fombrun, C.J. (1996) Reputation: Realizing Value from Corporate Image, Boston, MA: Harvard Business School Press.

Forstmoser, P. and Herger, N. (2006) 'Managing reputational risk: A reinsurer's view', The Geneva Papers on Risk and Insurance-Issues and Practice 31(3): 409-424.

Galai, D. and Masulis, R. (1976) 'The option pricing model and the risk factor of stock', Journal of Financial Economics 3(1\&2): 53-81.

Gaultier-Gaillard, S. and Louisot, J. (2006) 'Risks to reputation: A global approach', The Geneva Papers on Risk and Insurance-Issues and Practice 31(3): 425-445.

Hanley, K. (1993) 'The underpricing of initial public offerings and the partial adjustment phenomenon', Journal of Financial Economics 34(2): 231-250.

Hanley, K., Kumar, W. and Seguin, P. (1993) 'Price stabilization in the market for new issues', Journal of Financial Economics 34(2): 177-197.

Harrington, S.E. (2004) 'Market discipline in insurance and re-insurance', in C. Borio, W.C. Hunter, G. Kaufman and K. Tsatsaronis (eds.) Market Discipline Across Countries and Industries, Cambridge: MIT Press, pp. 159-173. 
Hoyt, R.E. and Liebenberg, A.P. (2011) 'The value of enterprise risk management', Journal of Risk and Insurance 78(4): 795-822.

Hughes, P. (1986) 'Signaling by direct disclosure under asymmetric information', Journal of Accounting and Economics 8(2): 120-142.

Johnson, J. and Miller, R. (1989) 'Investment banker prestige and the underpricing of initial public offerings', Financial Management 17(2): 19-29.

Keeley, M.C. (1990) 'Deposit insurance, risk and market power in banking', American Economic Review 80(5): 1183-1200.

Lai, G.C., McNamara, M.J. and Yu, T. (2008) 'The wealth effect of demutualization: Evidence from the U.S. property-liability and life insurance industries', Journal of Risk and Insurance 75(1): 683-711.

Leland, H. and Pyle, D. (1977) 'Information asymmetries, financial structure, and financial intermediation', Journal of Finance 32(2): 371-387.

Loughran, T. and Ritter, J. (2004) 'Why has IPO underpricing changed over time?' Financial Management 33(3): 5-37.

Polonchek, J. and Miller, R. (1999) 'Contagion effects in the insurance industry', Journal of Risk and Insurance 66(3): 459-475.

Power, M.L. (1983) 'Voluntary chapter 11: A risk management tool', Risk Management 30(12): 18-24.

Rahman, M., Burckel, D. and Mustafa, M. (2009) 'Accounting scandals and stock performance: Life after Enron', Journal of Business and Economics Research 7(3): 13-23.

Rayner, J. (2003) Managing Reputational Risk: Curbing Threats, Leveraging Opportunities, Hoboken, NJ: John Wiley and Sons.

Ritter, J. (1984) 'The 'hot issue' market of 1980', Journal of Business 57(2): 210-241.

Rock, K. (1986) 'Why new issues are underpriced', Journal of Financial Economics 15(1\&2): 187-212.

Ross, S. (1989) 'Institutional markets, financial marketing and financial innovation', Journal of Finance 44(3): 541-556.

Santomero, A. and Babbel, D. (1997) 'Financial risk management by insurers: An analysis of the process', Journal of Risk and Insurance 64(2): 231-270.

Schanz, K. (2006) 'Reputation and reputational risk management: Much discussed, little researched', The Geneva Papers on Risk and Insurance-Issues and Practice 31(3): 3-6.

Schurmann, S. (2006) 'Reputation: Some thoughts from an investor's point of view', The Geneva Papers on Risk and Insurance - Issues and Practice 31(3): 445-469.

Singh, A. and Power, M. (1992) 'The effects of Best's rating changes on insurance company stock prices', Journal of Risk and Insurance 59(2): 310-317.

Staking, K. and Babbel, D. (1995) 'The relation between capital structure, interest rate sensitivity and market value in the property-liability insurance industry', Journal of Risk and Insurance 62(2): 690-718.

Stansfield, G. (2006) 'Some thoughts on reputation and challenges for financial institutions', The Geneva Papers on Risk and Insurance-Issues and Practice 31(3): 470-479.

Stewart, G. (2006) 'Can reputations be "managed”?' The Geneva Papers on Risk and Insurance-Issues and Practice 31(3): 480-499.

Summers, S. and Sweeney, J. (1998) 'Fraudulently misstated financial statements and insider trading: An empirical analysis', The Accounting Review 73(1): 131-146.

Tinic, S. (1988) 'Anatomy of initial public offerings of stock', Journal of Finance 43(4): 789-822.

Titman, S. and Trueman, B. (1986) 'Information quality and the valuation of new issues', Journal of Accounting and Economics 8(2): 159-172.

Viswanathan, K. (2006) 'The pricing of insurer demutualization initial public offerings', Journal of Risk and Insurance 73(3): 439-468.

Wang, Q. and Ligon, J. (2009) 'The underpricing of insurance IPOs', Financial Management 38(2): 301-322.

White, H. (1980) 'A heteroskedasticity-consistent covariance matrix estimator and a direct test for heteroskedasticity', Econometrica 48(4): 817-838.

Zhang, T., Cox, L. and Van Ness, R. (2009) 'Adverse selection and the opaqueness of insurers', Journal of Risk and Insurance 76(2): 295-321. 


\section{About the Authors}

Richard B. Carter is the Dean's Professor of Finance at Iowa State University. He received his MBA and $\mathrm{PhD}$ from the University of Utah. Prior to this, he was Terminal Manager for Stott \& Davis Motor Express and Supervisor of EDP at Mutual of New York. His research interests include investment banking and capital acquisition. He has published in such journals as Journal of Finance, Financial Management and Journal of Financial and Quantitative Analysis.

Mark L. Power is University Professor and Principal Financial Group Finance Professor. He received his MBA and PhD from the University of Iowa. In addition to teaching in the areas of risk management and insurance, he has worked in the insurance industry and is involved extensively in research, consulting and in continuing education activities. Dr. Power's research has been published in such journals as the Journal of Risk and Insurance, the Journal of Insurance Regulation, The Journal of Accounting and Public Policy, Risk Management and Insurance Review, the Journal of Pension Economics and Finance and the Quarterly Review of Economics and Finance. 